\title{
EFFECTIVENESS OF CAUDAL EPIDURAL ANAESTHESIA IN ANORECTAL SURGERY.
}

\footnotetext{
1. FCPS (Surgery), MRCS (UK) Assistant Professor Department of Surgery Allama lqbal Medical College/ Jinnah Hospital Lahore.

2. FCPS (General Surgery), MCPS Assistant Professor Department of Surgical Unit-1 Ghulam Muhammad Mahar Medical College, Sukkur.

3. FCPS (General Surgery) Associate Professor Department of Surgery Ward-2 Jinnah Postgraduate Medical Centre Karachi.
}

Correspondence Address:

Dr. Sajid Malik

Department of Surgery

Allama Iqbal Medical College/

Jinnah Hospital Lahore.

drsajidmalik@yahoo.com

Article received on:

29/05/2018

Accepted for publication:

18/09/2018

Received after proof reading:

25/06/2019

\begin{abstract}
Sajid Malik', Shahid Hussain Mirani², Dileep Kumar ${ }^{3}$
ABSTRACT... To assess the effectiveness of caudal epidural anaesthesia in patients with anorectal surgical condition. Study Design: Prospective randomized study. Setting: Department of Surgery, Jinnah Hospital, Lahore. Period: $1^{\text {st }}$ August 2016 to $31^{\text {st }}$ July 2017. Materials and Methods: One hundred and eighty patients with general anorectal surgical conditions were recruited in this study with their consent. Patients were subject to surgery planned beneath caudal block. Results: One hundred and fifty eight patients (87\%) satisfy with the technique of anaesthesia and one hundred sixty six $(92.22 \%)$ patients demonstrate satisfaction with the postoperative pain control. One hundred and fifty two patients $(84.44 \%)$ were resisted with pre-operative information and $158(87 \%)$ patients show their consent to select this kind of anaesthesia if needed again. In 20 patients there was block failure caused about $11.11 \%$ failure rate. Conclusion: Satisfactory anaesthesia, minimal requirements, cost effectiveness and high patients acceptability make caudal anaesthesia a suitable choice for trivial and surgery.
\end{abstract}

Key words: Anaesthesia, Anorectal Surgery, Caudal Anaesthesia, High Patients Acceptability, Satisfactory Anaesthesia.

Article Citation: Malik S, Mirani SH, Kumar D. Effectiveness of caudal epidural anaesthesia in anorectal surgery. Professional Med J 2019; 26(7):1121-1124. DOI: 10.29309/TPMJ/2019.26.07.3779

\section{INTRODUCTION}

Local anaesthesia is frequent the method of selection for anal surgery but caudal anaesthesia is not well liked due to the increased failure rate as compared to spinal and epidural anaesthesia. For minor anorectal surgery, caudal anaesthesia is applicable. ${ }^{1,2}$

Caudal block involve inserting needle through sacral hiatus for medication into epidural space. This approach is also popular in managing patients with chronic pain conditions. ${ }^{3-5}$

It was firstly introduce as a landmark based, blind method. Above 96\% successful rate was found in children with this blind technique. ${ }^{1} \mathrm{CA}$ (caudal anaesthesia) is commonly used in children. ${ }^{6}$ In different settings caudal anaesthesia is performed in adult patients whom treating anorectal surgery. The safety and efficacy of caudal block for parineal and sacral methods have been resulted in adult patients. ${ }^{7}$ Many of studies shows that gender may be an important factor for examining anaesthetic fulfillness importantly for morphine. ${ }^{8}$

Minor anorectal disorders are common in adults in western countries. In USA, the frequency of hemorrhoids and other anorectal disorders in adult is $4 \%$ to $5 \%$ and approximately $10 \%$ of incidences required surgical treatment. ${ }^{9}$ In 1986 , L.E.Smith reported that $90 \%$ of anorectal surgeries is performed on the basis of ambulatory. ${ }^{10}$

Anorectal surgeryneed deep anaesthesiabecause the zone acquire many of nerve supply and is reflexogenic. ${ }^{11}$ Many of techniches regarding anaesthesia is performing worldwide such as general, caudal and spinal anaesthesia. ${ }^{12,13}$ Caudal anaesthesia was firstly performed in Paris 1901. The method was introduced in the pediatric surgery department and since from 2000 it is successfully performing in adult anorectal surgery. ${ }^{14}$ 
Recent study was conducted to evaluate the effectiveness of caudal epidural anaesthesia in patients with anorectal surgical condition.

\section{MATERIALS AND METHODS}

This prospective randomized study was conducted at Department of Surgery, Jinnah Hospital, Lahore from $1^{\text {st }}$ August 2016 to $31^{\text {st }}$ July 2017. One hundred and eighty patients were recruited with general anorectal surgical conditions during the period of this study. Under caudal block, surgery was planned in all patients. With standard 20-gauge needle established the caudal anaesthesia with prone positioned patients. The general anorectal conditions were included in the study like anal fissure, perianal abscesses, fistula and hemorrhoids. With standard hypodermic needle $20 \mathrm{~g}$ established the caudal anaesthesia with prone positioned patients. Identified the sacral hiatus and inserted needle in sacral canal and instilled the approximately $25 \mathrm{ml}$ of $0.25 \%$ bupivacaine injection. The required surgery process was done after thirty minutes. The data was entered and analyzed in SPSS-20.

\section{RESULTS}

There were 144 (80\%) male patients and 36 (20\%) female patients. The range of age was 16 years to 76 years, the mean age was $44 \pm 6.4$ (Table-I). Procedure carried out lateral sphincterotomy 56 , haemorrhoidectomy 66 , perianal abscess drainage 20 and fistulectomy 38 (Table-II). On the same evening all but twenty patients were discharge with post-operative stay, 6 hours and 13 minutes. There was anaesthesia failure in twenty 20 patients out of which general anaesthesia given to twelve 12 patients and completed procedure after anaesthesia augmentation in 8 patients with posterior perineal block. The feedback of patients regarding technique of caudal block anaesthesia, pre-operative analgesia as well as their satisfaction regarding pre-operative information was also obtained as shown in Table-III.

\begin{tabular}{|l|c|c|}
\hline \multicolumn{1}{|c|}{ Gender } & No. & $\%$ \\
\hline Male & 144 & 80 \\
\hline Female & 36 & 20 \\
\hline
\end{tabular}

Table-I. Distribution of gender $(n=180)$

\begin{tabular}{|l|c|c|}
\hline \multicolumn{1}{|c|}{ Gender } & N N & $\%$ \\
\hline Lateral Sphincterotomy & 56 & 31.11 \\
\hline Haemorrhoidectomy & 66 & 36.67 \\
\hline Perianal Abscess Drainage & 20 & 11.11 \\
\hline Fistulectomy & 38 & 21.11 \\
\hline
\end{tabular}

Table-II. Procedure performed $(n=180)$

\begin{tabular}{|l|c|c|}
\hline \multicolumn{1}{|c|}{ Feedback } & Yes & No \\
\hline $\begin{array}{l}\text { Is technique of caudal block } \\
\text { anaesthesia satisfying. }\end{array}$ & $158(87 \%)$ & $22(13 \%)$ \\
\hline $\begin{array}{l}\text { Is satisfying with pre- } \\
\text { operative analgesia. }\end{array}$ & $\begin{array}{c}166 \\
(92.22 \%)\end{array}$ & $14(7.78 \%)$ \\
\hline $\begin{array}{l}\text { Are satisfying with pre- } \\
\text { operative information. }\end{array}$ & $\begin{array}{c}152 \\
(84.44 \%)\end{array}$ & $\begin{array}{c}28 \\
(15.56 \%)\end{array}$ \\
\hline $\begin{array}{l}\text { If needed again, will select } \\
\text { caudal anaesthesia. }\end{array}$ & $158(87 \%)$ & $22(13 \%)$ \\
\hline \multicolumn{2}{|c|}{ Table-III. Patients feedback $(\mathbf{n = 1 8 0 )}$} \\
\hline
\end{tabular}

\section{DISCUSSION}

Caudal anaesthesia is inexpensive and easy. In 1990, Sicard and Cathelin firstly described caudal anaesthesia is promptly applicable to slight anorectal surgery. Until now, there is hesitation to execute rectal and anal procedure under caudal anaesthesia of fright of pre and post operative chronic pain. ${ }^{18,19}$ This stance has been changed slowly because of good control of pain by longish act anaesthetic drug. ${ }^{20}$ This anaesthesia technique can successfully deal with more than $80 \%$ of anorectal surgical conditions with economy and better expediency without scarifying ease and safety. ${ }^{21,22}$

There are many advantages offered by local anaesthesia i.e. decrease the recovery time of patients, limit post-anaesthesia nursing care and decreases the quantity of analgesics needed in the instant postoperative period. ${ }^{22}$ Caudal epidural anaesthesia is very easy to execute and is effective and safe. The success depends on accurate selection of patients. The rate of success is better in adult patients. With the age passes, the caudal epidural space fat becomes fibrosed and much organized therefore correct dissipation of fluid is not possible sometimes. Due to this reason the rate of failure is minor high in caudal block as compare to saddle/encumber anaesthesia however, it has got different advantage of good quality and longish period of 
post-operative analgesia. ${ }^{3,22}$ The average period of epidural analgesia with $0.25 \%$ bupivacaine was 8 hours to 12 hours in a study done by Miles and Dunkley ${ }^{23}$ which is little higher compare to 4 to 8.5 hours in this study. Gabrielli and colleagues ${ }^{24}$ observed one hundred and ninety three patients even long period of analgesia in their study. The patients with satisfactory anaesthetic effect was better sphincter relaxation and was experience least uneasiness.

In the light of feedback in response to questionnaire, $88.88 \%$ patients satisfied from preoperative information and patients showing their readiness to select this kind of anaesthesia, if required again which is according to the study of Thompson ${ }^{19}$ of 129 patients in which they believed that they received sufficient information were $86 \%$. Their conclusion that patients toleration and adequacy remain high and with the high degree of patients contentment / satisfaction day case proctology can be performed which was same as in other international studies. ${ }^{24-25,26}$ The decrease of patients hospital stay treat for anorectal surgical condition is an attractive substitute that decreases the cost without increased the morbidity. Furthermore, it is cost effective, safe and decreases the load of work on elective list.

\section{CONCLUSION}

Satisfactory anaesthesia, minimal requirements, cost effectiveness and high patients acceptability make caudal anaesthesia a suitable choice for trivial and surgery. Further, it is safe and decreases the load of work on elective list.

\section{Copyright(C) 18 Sep, 2018.}

\section{REFERENCES}

1. Yang HK. Day-case hemorrhoidectomy. In: Hemorrhoids. Berling: Springer, 2014.

2. Kushwaha R, Hutchings W, Davies C, Rao NG. Randomized trial comparing day-care open haemorrhoidectomy under local general anaesthesia. Br J Surg 2008; 95: 555-63.

3. Gupta PJ. Feasibility of day care surgery in proctology. J Gastrointestin Liver Dis 2006; 15(4): 35962.
4. Gabrielli F, Chiarelli M, Cioffi U, Guttadauro A, De Simone M, Di Mauro P, et al. Day surgery formucosal -hemorrhoidal prolapse using a circular stapler and modified regional anesthesia. Dis Colon Rectum $2001 ; 44: 842-4$.

5. Gabrielli F. Regional anaesthesia in proctological day-surgery: BJS 1996; 11:834.

6. Giaufre E, Dalens B, Gombert A. Epidemiology and morbidity of regional anesthesia in children: $A$ oneyear prospective survey of the French-Language society of pediatric anesthesiologists. Anesth Analg 1996; 83:904-12.

7. Adebamowo CA. Caudal anesthesia in the clinical assessment of painful anal lesions. Afr $\mathrm{J}$ Med Med Sci 2000; 29:133-4.

8. Okeke LI. Experience with caudal block regional anesthesia for transurethral resection of the prostate gland. West Afr J Med 2002; 21:280-1.

9. Gudaityte J, Marchertiene I, Pavalkis D. Anesthesia for ambulatory anorectal surgery. Medicina 2004; 40:101-11.

10. $\mathrm{Xe} F$, Feng $Y X$, Lin JJ. A ropivacainelidocaine combination for caudal blockade in haemorrhoidectomy. J Int Med Res 2007; 35:307-13.

11. Cepeda MS, Carr DB. Women experience more pain and require more morphine than men to achieve a similar degree of analgesia. Anesth Analg 2003; 97:1464-8.

12. Li S, Coloma M, White PF, Watcha MF, Chiu JW, Li H, HuberPJ. Comparison of the costs and recovery profiles of threeanesthetic techniques for ambulatory anorectal surgery. Anesthesiology 2000; 93(5):122530.

13. Smith LE. Ambulatory surgery for anorectal diseases: An update South Med J 1986; 79(2):163-6.

14. Erdman AG. Concise anatomy for anaesthesia. Sacral plexus, the autonomic nervous system. London: Greenwich Medical Media; 2002. p. 56, 59, 70-5.

15. Van Elstraete AC, Lebrun FP. Costs and recovery profiles of caudal anesthesia for anorectal surgery in adults. Anesthesiology 2001; 95(3):813-4.

16. Van Elstraete AC, Pastureau F, Lebrun T, Mehdaoui $\mathrm{H}$. Caudal clonidine for postoperative analgesia in adults. Br J Anaesth 2000; 84(3):401-2. 
17. Gudaitytè J, Marchertienè I, Pavalkis D. Kaudalinè blokada suaugusiujų anorektalinèje chirugijoje. (Caudal blocade for adult patients in anorectal surgery.) Sveikatos mokslai 2002; 5:11-14.

18. Henriques AC, Horta SH, Pezzolo S, Waisberg J, Boratto SF, Helal $S$, et al. Surgical procedures in selected proctological patients with local anesthesia: study of 150 cases. Arq Gastroenterol 2000; 37(3):158-61.

19. Thompson MW, Cook TA. What patient thinks of day surgery proctology. BJS 2006; 85: 1388-90.

20. Lin JK. Preservation of anal sphincter function after hemorrhoidectomy under local anesthesia. Zhongua Yi Xue Za Zhi 2001; 64(9):519-24.

21. Pietroletti R, Navarra L, Cianca G. Proctological surgery in the one-day surgery regimen: the preliminary results with 232 patients. Ann Ital Chir. 2012; 69(4):499-503.

22. Carditello A, Meduri F, Cardillo P.: Proctologic daysurgery: Results of $\mathbf{2 0 0 0}$ surgical interventions] Chir Ital 2001; 53(2):219-24.
23. Kazemeini A, Rahimi M, Fazeli MS, Mirjafari SA, Ghaderi $H$, Fani $K$, et al. The effect of local injections of bupivacaine plus ketamine, bupivacaine alone, and placebo on reducing postoperative anal fistula pain: A randomized clinical trial. Sci World J 2014; 2014: 424152.

24. Miles AJ, Dunkley AJ. Day case haemorrhoidectomy. Colorectal Dis 2007; 9(6):532-5.

25. Gabrielli F, Cioffi U, Chiarelli M, Guttadauro A, De Simone M. Hemorrhoidectomy with posterior perineal block: Experience with 400 cases. Dis Colon Rectum 2000; 43(6):809-12.

26. Halverson A. Hemorrhoids. Clin Colon Rectal Surg 2007; 20(2):77-85.

27. Wong LS, Kaukuntla HK, Lam FT, Fraser IA. Survey of patient satisfaction after day case surgery. Int J Clin Pract 2012; 53(3):189-91

28. Weale AR, Lear PA, Mitchell DC. Is day case surgery the key to basic surgical training? Ann R Coll Surg Engl 2002; 84(6):426-8.

\begin{tabular}{|c|c|c|c|}
\hline \multicolumn{4}{|c|}{ AUTHORSHIP AND CONTRIBUTION DECLARATION } \\
\hline Sr. \# & Author-s Full Name & Contribution to the paper & Author $=$ s Signature \\
\hline $\begin{array}{l}1 \\
2 \\
3\end{array}$ & $\begin{array}{l}\text { Sajid Malik } \\
\text { Shahid Hussain Mirani } \\
\text { Dileep Kumar }\end{array}$ & $\begin{array}{l}\text { Data collection \& writing of } \\
\text { manuscript. } \\
\text { Writing of manuscript and } \\
\text { compiling results. } \\
\text { Statistical analysis \& } \\
\text { guidance in writing the } \\
\text { manuscript. }\end{array}$ & 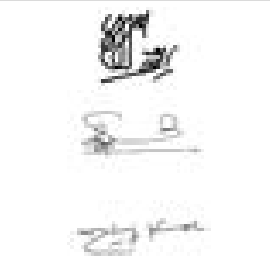 \\
\hline
\end{tabular}

